\title{
Retained Specimens Contain DNA
}

National Cancer Institute

\section{Source}

National Cancer Institute. Retained Specimens Contain DNA. NCI Thesaurus. Code C127777.

An indication that the retained biospecimens contain DNA. 